\title{
O ESPECTRO MILITAR NA LITERATURA DO INÍCIO DA REPÚBLICA DE WEIMAR (1919-1922) UMA ANÁLISE DA CRÍTICA DE KURT TUCHOLSKY
}

\author{
Anderson Roszik \\ USP-CAPES
}

RESUMO: 0 objetivo deste artigo é analisar como Kurt Tucholsky (1890-1935), nos anos iniciais da República de Weimar, tece sua crítica à presença do estrato militar na recém instaurada democracia alemã. 0 percurso elaborado por Tucholsky consiste em discussões sobre obras pertencentes a um dos principais campos de interesse de escrita da época: 0 da literatura de guerra, fração do campo literário importante para a compreensão do contexto imediato pós Primeira Guerra Mundial (19141918). Escritas por oficiais na forma de memórias, tais obras versam sobre a constituição das estruturas militares e suas correspondentes hierarquias até o desenvolvimento do aparelho oficial e seu controle na veiculação de notícias na imprensa. A análise dos textos de Tucholsky, publicados no periódico die Weltbühne, possibilita entrever as imbricações políticas, sociais e culturais da queda do sistema imperial e de seus estratos constitutivos face à crise estrutural nos primeiros anos de vida da república.

PALAVRAS-CHAVE: Kurt Tucholsky. República de Weimar. Militarismo.

\section{THE MILITARY STRATUM IN THE LITERATURE OF THE DAWN OF THE WEIMAR REPUBLIC (1919-1922) AN ANALYSIS OF KURT TUCHOLSKY'S CRITICISM}

ABSTRACT: This article analyzes how Kurt Tucholsky (1890-1935), in the early years of the Weimar Republic, makes his criticism of the presence of the military stratum in the newly established German democracy. Tucholsky's course consists of discussions of works belonging to one of the main writing fields of his time: war literature. Written by officers in the form of memories, these works deal with the constitution of the military and their corresponding hierarchies to the development of the official apparatus and its control in the disclosure of news in the press. The analysis of Tucholsky's texts, all published in the journal die Weltbühne, allows to carry out a review of the political, social and cultural aspects related to the fall of the imperial system and its constitution due to the structural crisis in the early years of the republic life in Germany.

KEYWORDS: Kurt Tucholsky. Weimar Republic. Militarism.

é Doutorando em Língua e Literatura Alemã na Faculdade de Filosofia, Letras e 


\title{
O ESPECTRO MILITAR NA LITERATURA DO INÍCIO DA REPÚBLICA DE WEIMAR (1919-1922) UMA ANÁLISE CRÍTICA DE KURT TUCHOLSKY
}

\author{
Anderson Roszik
}

\section{A REPÚBLICA DE WEIMAR: O NASCIMENTO DA E NA QUEDA DO SISTEMA IMPERIAL}

A República de Weimar (1918-1933) nasce dos escombros da Primeira Guerra Mundial (1914-1918) e marca o fim do Kaiserreich, iniciado em 1871. Além do fato histórico, o primeiro regime democrático em solo alemão salienta contradições internas marcadas pela tentativa de fazer coexistir o processo de alterações culturais, econômicas, políticas e sociais iniciados pela modernidade, sob cuja sombra despontam as raízes da guerra. Como pretendemos expor, neste trabalho, os quinze anos de existência da república são um interlúdio, um palco no qual se ensaiam os primeiros passos - trêmulos e periclitantes, em todo caso - da tentativa de rompimento com o antigo regime. Entretanto a ruptura não é completa.

A república surge, no entanto, como um retrocesso aos olhos daqueles que veem na guerra o processo de purificação necessário para o aperfeiçoamento do próprio homem. Tal visão encontra seu representante no estrato militar do período imperial, alimentado pelo ambiente no qual o habitus guerreiro fomenta o espírito apologista para o combate. Característico desta classe é o apelo à violência como fator intrínseco ao homem, o que serve à "afirmação irrestrita do negativo, da destruição e da morte" ${ }^{1}$ : tais elementos, vivos ainda em Weimar, cunham as forças presentes na catastrofização festejada no início do século XX.

A dupla configuração inicial do sistema republicano de Weimar - a democracia ocidental e o incipiente paradigma comunista - não apenas obedece à tentativa política de ocupar o vácuo deixado pelo antigo regime, mas, do ponto de vista político, também suprime as forças revolucionárias que surgem

\footnotetext{
${ }^{1}$ WEYERGRAF, Bernhard. Konservative Wandlungen. In: WEYERGRAF, Bernhard (Org.). Hansers Sozialgeschichte der deutschen Literatur vom 16. Jahrhundert bis zur Gegenwart. Begründet von Rolf Grimmiger. Band 8: Literatur der Weimarer Republik. 1918-1933. München: Carl Hanser, 1995, p. 270.
} 
como anseio de quebra das amarras do ancien regime. Consequentemente, o fora do lugar das ideias em Weimar é um elemento que modela tanto o engajamento na produção da arte dos representantes da literatura pró-guerra quanto o de sua contracorrente, a literatura antiguerra.

A maneira diametralmente oposta de lidar com a experiência da guerra uma experiência empobrecida de comunicação ${ }^{2}$ - cria a polarização entre "pacifistas" e "militaristas", com raízes que antecedem ao nascimento da república e que tonalizam sua abordagem na literatura. Uma perspectiva é a literatura pró-guerra, produzida já no período imperial (1871-1918), e da qual participam autores que deificam a guerra com o intuito de despertar no leitor a catarse através da descrição romântica e heroicizada dos atos de violência, transformada em "uma experiência arrebatadora em que o indivíduo perde sua própria identidade especial."3 É a apoteose do código de conduta do guerreiro enraizado no habitus feudal de honra e coragem e de "glorificação do horror."4 Isto no campo literário é agregado ao apelo à guerra como característica inata do homem.

No início da república, as obras que defendem a guerra, exaltando-a como "experiência íntima" e "superação das convenções civis" 5 , mostram a resistência do estrato militar ao processo civilizador, na medida em que se contrapõe à restrição do uso da violência em estados industrializados e unificados. É nessa fração do campo social que a literatura pró-guerra, ao estatuir-se como instrumento ideológico e de propaganda ${ }^{6}$, coloca-se igualmente como princípio ativo no processo de desestruturação do sistema democrático, diante do qual a contracorrente da literatura antiguerra lança suas críticas, com efeitos mais na esfera das reflexões do que na das ações práticas. Se os apologistas romantizam as imagens bélicas com o catártico intuito, dentre outros, de agregar seguidores por meio da "fácil loquacidade da forma e mediocridade

2 BENJAMIN, Walter. O narrador. Considerações sobre a obra de Nikolai Leskov. In: Magia e técnica, arte e política: ensaios sobre literatura e história da cultura. Trad. Sergio Paulo Rouanet. São Paulo: Brasiliense, 1994, p. 198.

${ }^{3}$ ELIAS, Norbert. A literatura pró-guerra da República de Weimar (Ernst Jünger). In: Os alemães: A luta pelo poder e a evolução do habitus nos séculos XIX e XX. Trad. Álvaro de Cabral. Rio de Janeiro: Zahar, 1997, p. 190.

${ }^{4}$ Ibidem, p. 191.

${ }^{5}$ Cf. WEYERGRAF, Bernhard. Konservative Wandlungen, op. cit., p. 270.

6 ELIAS, Norbert. A literatura pró-guerra da República de Weimar (Ernst Jünger), op. cit., p. 193. 
do conteúdo"7 , a literatura antiguerra elimina os vestígios de descrições de um hedonismo aguerrido e purificador e é considerada como traidora pelos círculos conservadores de tradição antimoral do período imperial.

Outra diferença é a posição militar descrita em termos literários e que determina toda uma visão sobre a guerra. Nesse sentido, a literatura pró-guerra divide-se em dois tipos: (i) em memórias escritas por oficiais de alta patente, que se amparam na recorrência a documentos para justificar a "lenda da punhalada nas costas" ${ }^{\prime \prime}$, e (ii) em escritas feitas por oficiais subalternos, que buscam fazer apologia à "liderança exercida pela corporação oficial imperial."9 Inerente aos oficiais de baixa patente, homens de origem burguesa que assimilam o código aristocrático do oficialato alemão baseado na tradição anticivilizadora da conduta guerreira ${ }^{10}$, é a falta de substrato cultural preenchida pela experiência redentora de guerra. Esta se caracteriza como principal poder simbólico no desejo de estabelecer um governo militar e derrubar o sistema democrático, seu antagonista nas relações de gradiente de poder. A assimilação do modelo de conduta alheio faz com que a guerra, valor de posse da classe nobre, seja algo a ser possuído como integrante de sua segunda natureza.

É neste contexto dos anos iniciais da República de Weimar - nosso recorte compreende os anos entre 1919 a 1922 - que está inserida a obra de Kurt Tucholsky. Jornalista de esquerda e crítico literário no periódico die Weltbühne, "leitura obrigatória para todos os que se consideravam intelectuais de esquerda", 11 Tucholsky dedica-se à discussão de obras que compõem uma fração do campo literário cuja criação é impulsionada pela experiência bélica dos anos 1914-1918, período no qual, para o autor, o instrumento de

7 BENJAMIN, Walter. Teorias do fascismo alemão. Sobre a coletânea Guerra e guerreiros, editada por Ernst Jünger. In: Magia e técnica, arte e política: ensaios sobre literatura e história da cultura, op. cit., p. 68.

8 A "lenda da punhalada nas costas" é criada pelo Alto Comando do Exército para imputar a culpa pela derrota na guerra ao governo socialdemocrata e, por consequência, livrar-se das consequências vindouras das cláusulas de rendição, principalmente as do Tratado de Versalhes. A "lenda" encontra plena recepção no contexto de crise estrutural no início da década de vinte e cria anseios de vingança contra os representantes do novo governo.

${ }^{9}$ BARON, Ulrich et al. Weltkriege und Kriegsromane. Die literarische Bewältigung des Krieges nach 1918 und 1945 - eine Skizze. Zeitschrift für Literaturwissenschaft und Linguistik, Göttingen, n. 75, 1989, p. 17.

${ }^{10}$ Cf. ELIAS, Norbert. A literatura pró-guerra da República de Weimar (Ernst Jünger), op. cit., p. 193.

${ }^{11}$ SUHR, Elke. Zwei Wege, ein Ziel. Tucholsky, Ossietzky und Die Weltbühne. München: Weismann, 1986, p. 16. 
censura militar e as consequentes falsas notícias enviadas pelos comandos de guerra alemães configuram estratégias de manobra política exercidas pelos militares.

O espírito militar não se extingue em 1918; ao contrário: permanece presente na república como parte da estrutura política que nasce da e na derrocada do império. O novo sistema ainda é uma ponte frágil sobre seu próprio abismo e sobre a qual se agitam antagonismos sociais que se refletem no campo intelectual. ${ }^{12}$

\section{O ESPECTRO MILITAR E A CRÍTICA DE KURT TUCHOLSKY}

\subsection{O OFICIAL DO FUTURO: INTRODUÇÃO À CRÍTICA DE TUCHOLSKY}

O primeiro texto crítico ${ }^{13}$, intitulado $O$ oficial do futuro, refere-se à obra $O$ oficial alemão do futuro, escrita por Arno Voigt. ${ }^{14} \mathrm{O}$ artigo, que aborda uma obra pertencente ao filão da corrente antiguerra e publicado no ano de 1919 , é paradigmático quanto ao fio condutor de textos políticos que tematizam a conduta militar durante a guerra. Assim Tucholsky inicia sua crítica:

\footnotetext{
"Talvez", disse Nietzsche certa vez, "eu nunca tenha lido algo que teria negado de tal modo, sentença por sentença, conclusão por conclusão, como a este livro: porém totalmente sem desgosto e impaciência". Aliás, a nota introdutória é excelente. Ela resume novamente os severos pecados das corporações de oficiais durante uma guerra que tomou dos oficiais alemães para sempre a reputação de inimputabilidade, e com razão. Pessoas que, ainda hoje, se atêm ao velho ídolo, o fazem por motivos políticos - não querem reconhecer, e por isso não merecem ser convencidos. Nós, outros, sabemos o que confirma Voigt: "Oficiais - burgueses - soldados: esta era a estrutura." ${ }^{15}$
}

Após defender Arno Voigt como "um dos raros oficiais alemães que não se amedrontou em dizer a verdade durante a guerra"16, Tucholsky traz à baila um pequeno trecho de Nietzsche como síntese do que poderia ser comentado

12 GAY, Peter. A cultura de Weimar. Rio de Janeiro: Paz e Terra, 1978, p. 15.

13 Destacamos que as traduções de todos os textos de Kurt Tucholsky presentes neste trabalho são traduções nossas.

${ }^{14}$ Com a exclusão do adjetivo "alemão" do título do artigo, Tucholsky amplia a esfera de abrangência de sua crítica: a mudança de atitude postulada deve atingir a classe militar além das fronteiras nacionais.

15 TUCHOLSKY, Kurt. Der Offizier der Zukunft. In: GEROLD-TUCHOLSKY, Mary; RADDATZ, Fritz J. (Org.). Gesammelte Werke. Reinbek bei Hamburg: Rowohlt, 1993a, p. 109.

16 Ibidem. 
sobre o livro, acrescentando-lhe suas próprias palavras de censura. Oficiais que durante a guerra roubam pelo simples prazer de roubar desfrutam de um luxo incompatível com o estado de miséria que se agrava no país nos anos finais de guerra. No trecho da obra de Voigt, ressalta-se a falta de uma visão capaz de perceber a permanência dos espíritos militares nos seios civil e político e a consequente idolatria desses espíritos por grande parte da população, no início da guerra, assim como fora em 1914: a República de Weimar constrói-se com fantasmas imperiais.

Discutir as manifestações do espírito militar no passado, todavia, seria conservar uma visão neste e deste momento histórico. A base do texto de Tucholsky consiste no questionamento da hipotética alteração, num tempo futuro, do mesmo espírito militar e de suas relações com o sistema políticosocial. O crítico elucida, assim, sua busca por uma reorientação na realidade pós-guerra:

\begin{abstract}
O soldado alemão do futuro deve ser um ser humano dotado de espírito. Isto é, em suma, o postulado deste oficial que, certamente, foi um bom oficial. Com razão exige do Führer qualidades superiores àquelas que se destacaram nos miseráveis exames para oficiais e na deficiente educação dos cassinos: ele exige qualidades humanas. ${ }^{17}$
\end{abstract}

Exigir dos oficiais virtudes é, para Tucholsky, uma utopia. Os militares constituem um estrato que, sob a égide de Bismarck (1871-1890) e GuiIherme II (1891-1918), representam o espírito da época, a partir do qual o culto exacerbado ao poder e a presença do espírito de submissão expressam a assimilação do código de conduta imperial (principalmente após 1891), e não poderia sofrer alterações tão profundas como as sugeridas por Voigt. O valor dos textos críticos de Tucholsky consiste no desenvolvimento da análise com a imbricação das relações entre o contexto imediato e o histórico das narrativas não-ficcionais da literatura pró-guerra e antiguerra.

Em seguida, Tucholsky afirma: "Se o oficial do futuro seguir todos estes bons conselhos de Voigt, talvez se torne um nobre e [...] um Führer para seus camaradas: mas ele não derramará sangue segundo a vontade do Estado." ${ }^{18} \mathrm{~A}$ última sentença expressa a conduta dos oficiais e suas relações de subordinação com o Estado comandado pelo imperador Guilherme II - estrutura social

${ }^{17}$ Cf. TUCHOLSKY, Kurt. Der Offizier der Zukunft, op. cit., p. 110.

18 Ibidem. 
hierárquica baseada em valores aristocrático-militares durante o Kaiserreich.

A imutabilidade do espírito oficial alemão - "estúpido militarismo", para Hanna Arendt ${ }^{19}$ - se transforma num modelo universal devido, dentre outros fatores, à supressão do adjetivo "alemão" do título da obra no texto de Tucholsky e é característico antes e depois do combate: novamente a hierárquica submissão do período pré-guerra mostra-se atual. O texto crítico de Tucholsky, com a sua posição contrária a estes fatores, é válido enquanto análise de obras não literárias, considerando-as alvo de discussões, dentro de uma visão ideológica que busca esclarecer as questões em torno da figura do oficial.

\subsection{O LIVRO DE CULPAS: A HIERARQUIA MILITAR EM FOCO}

No próximo texto crítico, intitulado O livro de culpas e veiculado em 1919, é discutida a publicação de um conjunto de documentos oficiais organizados pela chancelaria do Reich e intitulado Antecedentes do armistício. Nesta seleção de documentos revelam-se aspectos da organização militar alemã em várias vertentes, como sua hierarquia interna e notícias veiculadas sobre o desenvolvimento dos combates, quase sempre falsas. A hierarquia militar reveste-se de maior importância se se observar sua presença, durante a república, na configuração de grupos que fazem uso de gradientes distintos de violência: enquanto estratos superiores tornam-se membros do exército oficial, categorias inferiores criam grupos extra-estatais que lançam mão da violência na perpetração de atos contra o sistema democrático.

A crítica aos militares realizada por Tucholsky não pressupõe nem desemboca na defesa de um partido político - seja o Partido Social-Democrata ou o Partido Comunista: ela advoga pelos ideais proletários sem o uso da violência, postura humanista que se coloca frente aos problemas do momento. Os textos de crítica política, nos quais o termo "crítica" pode ser equiparado a repúdio, ridicularizarão os responsáveis pelo caos interno da república.

Os Antecedentes do armistício são uma obra-prima. Como as figuras aparecem plasticamente! Quão vivos são os homens, os líderes do exército, os funcionários públicos, o Kaiser, os Secretários de Estado - quão vivas vão-se desenvolvendo paulatinamente as coisas rodopiantes que se desenvolvem ocultas atrás da

${ }^{19}$ ARENDT, Hannah. O sistema totalitário. Lisboa: Publicações D. Quixote, 1978, p. 99. 
tranquilidade aparente dos trechos de processos! A lei antiga da arte se concretizou pela primeira vez aqui: atividade apaixonada dos acontecimentos e paz objetiva da representação. ${ }^{20}$

Neste excerto do ensaio de Tucholsky, emerge a representação da nova sociedade republicana alemã, ainda que com suas várias contracorrentes ideológicas $^{21}$, as quais são, no início e final da década de vinte, rapidamente postas em prática contra o regime republicano. Com aguda ironia à linguagem dos documentos, a crítica do autor é jocosa não apenas na esfera metalinguística - a desprezível arte retórica da obra - mas também em termos de construção literária ao ridicularizar a posição dos personagens apresentados. Ao afirmar que as verdadeiras circunstâncias são reais apenas para os documentos da esfera política, regida por interesses de altos funcionários imperiais e militares, Tucholsky estende ironicamente o argumento para a esfera escrita: se há alguma relação entre arte e o documento, essa só está no plano da representação de interesses. E um dos principais interesses do documento é ocultar as fendas do declínio cediço do regime imperial e as rupturas estruturais que originam o incômodo não-lugar militar.

Ora, para uma nação cuja fragilidade estrutural do Estado é um fator marcante em seu desenvolvimento social, o declínio da posição de poder hierárquico - mas não da hierarquia - alcançado pelas bases militares durante a nova República não é vista como um simples fator histórico. O processo de batalhas externas, da qual a guerra de 1914-1918 é um expoente, produz entre os alemães uma reação que levou a "conduta militar e as ações bélicas a serem respeitadas e, com frequência, idealizadas." ${ }^{22}$ Os reflexos entre a camada dominante de uma possível volta às derrotas causam um abalo na ideologia interna que busca, de diversas maneiras, dissipá-los. Nessa perspectiva de leitura, a obra documental analisada por Tucholsky torna-se um paradigma desse tipo de atitude.

O crítico produz algumas considerações sobre a conduta dos oficiais du-

20 TUCHOLSKY, Kurt. Schuldbuch. In: GEROLD-TUCHOLSKY, Mary; RADDATZ, Fritz J. (Org.). Gesammelte Werke, op. cit., p. 145.

${ }^{21}$ Ideologia, neste sentido, é compreendida como "sistemas baseados numa única opinião suficientemente forte para atrair e persuadir um grupo de pessoas e bastante ampla para orientá-las nas experiências e situações da vida moderna. [...] Toda ideologia que se preza é criada, mantida e aperfeiçoada como arma política e não como doutrina teórica." ARENDT, Hanna, O sistema totalitário, op. cit., p. 224-225.

22 ELIAS, Norbert. Introdução. In: A literatura pró-guerra da República de Weimar (Ernst Jünger), op. cit., p. 20. 
rante e depois da guerra. A coletânea Antecedentes do armistício expõe os aspectos negativos do comportamento militar como um modelo a ser seguido: a coação exercida pelos militares a qualquer custo se torna uma espécie de fio condutor. Esse comportamento condenado por Tucholsky é descrita na obra por meio de uma linguagem censurável, que confere à obra um status longínquo da literatura:

Antes que eu comece, quero ressaltar que a língua é atropelada - estilo de ata; exatamente através disso alcança-se o jargão da elite do exército de Potsdam. Generais lançaram trastes - mas infelizmente quebrou uma caixa inteira de porcelana. ${ }^{23}$

É através da crítica à linguagem da obra - "linguagem decepada pelo estilo protocolar" - que Tucholsky revela o cerne do problema: novamente centrado na questão dos representantes dos estratos nobres e militares no processo de formação do Estado alemão. Para as figuras militares e para a grande parcela da população, o conflito com países como a França ou a Inglaterra seria a única maneira de conferir ao Estado alemão algo que aqueles já possuíam, ou seja, a unidade política. Conceber assim o conflito torna-se a única salvação possível, além de um pensamento retomado no decorrer da década de vinte entre os mais extremistas agressores da república, a maioria deles sobreviventes da guerra e simpatizantes de movimentos contrários à democracia.

Observamos, até o momento, como o cenário configurado durante a guerra de 1914-1918 e os anos iniciais da República de Weimar influenciam a escrita de obras pró-guerra ou antiguerra, as quais constituem parte integrante das alterações pelas quais passam o habitus da nação. Os textos de crítica política de Tucholsky, referentes às obras não literárias, exploram essas modificações dentro do seu espectro de criação, ou seja, do das personalidades envolvidas nos setores dominantes. Eles auxiliam para a explanação dos aspectos adjacentes da literatura, no início da década de 1920, na Alemanha, na medida em que discutem as especificidades das relações sociais baseadas nos militares como pano de fundo para a elaboração do discurso literário.

$\mathrm{Na}$ crítica à obra Antecedentes do armistício, encontramos trechos originários do alto escalão do exército, expressos, segundo o crítico, pelo ma-

${ }^{23}$ Cf. TUCHOLSKY, Kurt. Schuldbuch, op. cit., p. 145. 
jor Von dem Bussche ${ }^{24}$, no dia 2 de outubro de 1918:

"O exército alemão ainda é forte suficiente para deter o exército inimigo durante meses a fio, alcançar êxitos regionais e causar baixas à entente". E ele mesmo se pronuncia na Grande Audiência de quatorze de outubro: "Se o exército atravessar nas próximas quatro semanas e o inverno cair, então teremos sorte." 25

Torna-se visível um fato constante no exército alemão durante a I Guerra: a manipulação, por parte do exército, das verdadeiras condições de batalha e das respectivas notícias. Talvez a derrota, em 1918, não seja advinda somente da batalha em duas frentes (oeste e leste, contra a França e o consequente ataque contra a Rússia após longa defensiva prevista no Schlieffen-Plan): ${ }^{26}$ a dificuldade em aceitar o desenvolvimento contrário aos sonhos de grandeza imperial alemã está presente nas atitudes bélicas e, em virtude do domínio exercido pelos militares, em parte da imprensa do período.

Não podemos esquecer que a República de Weimar é fundada no dia 9 de novembro de 1918, e o documento sobre a "real" condição do exército data de 14 de outubro; certamente, um prazo bastante curto para a estabilização necessária à vida política da nação, que está destinada ao abismo nos primeiros meses do ano. $O$ exército alemão vê no Tratado de Paz de Brest-Litowski, assinado no mês de março de 1918, uma possibilidade real de ataque contra a Rússia, no leste, enquanto uma posterior contraofensiva no oeste, no mês de agosto, viria a marcar a derrota do exército comandado por Hindenburg e Ludendorff.

Esse último é criticado severamente por Tucholsky quanto à postura assumida no final do combate, cujas consequências são, dentre outros aspectos, o Tratado de Versalhes, marca da derrota política e moral do país. A imposição torna-se a mácula do sentimento nacional, dado que ao mesmo tempo sombra intempestiva durante toda a década de 1920 e um dos pilares da

\footnotetext{
${ }^{24}$ Tucholsky se refere a Erich von dem Bussche-Ippenburg (1878-1957), major do exército prussiano que, conforme o exemplo (igualmente paradoxal) de outros oficiais de alto escalão, compõe a formação militar de Weimar.

${ }^{25}$ Cf. TUCHOLSKY, Kurt. Schuldbuch, op. cit., p. 146-147.

${ }^{26} \mathrm{O}$ Schlieffen-Plan constitui-se na estratégia de ataque à França e Bélgica, ao oeste, não apoiando a Áustria no ataque leste contra a Rússia e a Sérvia. Enquanto mantinham uma frente de ataque no oeste, mantinham outra de defesa e posterior ataque no leste, após a invasão da Bélgica.
} 
desfiguração do exército prussiano ${ }^{27}$, considerado a mais significativa autoimagem do império. Mais do que o conteúdo do tratado, um fato que marca sua assinatura e seus efeitos políticos está intimamente ligado aos acontecimentos destacados a seguir pelo crítico:

Agora, responsabilizem-no, então! Livrem-no hoje da responsabilidade, então! Ele se referiu a ela quando não custava nada - e fugiu quando existia o perigo de termos uma Alemanha revolucionária, fugiu para a Suécia e só retornou quando tudo transcorria segundo os ensejos burgueses. Ele é responsável! Ele não o é, perambula por aí e permanece sem punição - até os dias atuais. ${ }^{28}$

Após destacar que a dificuldade principal em conquistar o povo búlgaro seria o desconhecimento linguístico, o crítico enfatiza novamente sua posição face ao militar e afirma que o general "penetrou tão pouco na alma alemã

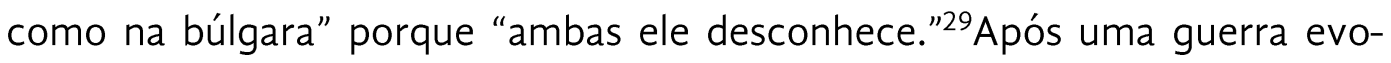
cada e perdida pelo espírito militar imperial, seria natural que os mesmos representantes fossem incumbidos de assinar os papéis referentes à derrota, fato que não ocorre: as palavras do crítico mostram que, após o mês de outubro, as atitudes de Ludendorff - que busca passar a imagem de um exército ileso - convergem para o completo afastamento da designação para assinar o Tratado.

Isso tem resultados imediatos: os constantes assassinatos políticos, como o de Matthias Erzberger, ministro incumbido de assinar o tratado de paz em 1919 - e posteriores - a própria falta de confiança nos dirigentes políticos, traidores da nação aos olhos dos conservadores. A não assinatura do tratado pelos comandantes dos exércitos alemães é combatida pelo crítico, para quem o general tornar-se-ia o expoente máximo do espírito impune dos militares. A posterior e vergonhosa fuga da figura do militar para a Suécia também é um constante motivo de zombaria por Tucholsky, que passa a referir-se ao general por "Ludendorff-Lindström", em alusão à cidade na qual se refugia antes de abandonar o país.

As diferentes vertentes de pensamento político e intelectual da república se estruturam no decorrer da guerra e se ramificam a partir de 1918. As

\footnotetext{
${ }^{27}$ ROSERBERG, Arthur. Die gesellschaftlichen Kräfte unter Bismarck. In: Die Entstehung der Republik. Berlin: Rowohlt, 1928, p. 11.

${ }^{28}$ Cf. TUCHOLSKY, Kurt. Schuldbuch, op. cit., p. 148.

29 Ibidem, p. 149.
} 
discussões de Tucholsky sobre as obras escritas por militares mostram como impunidade e desrespeito às leis que se agregam no exército e em parte do escalão politicamente ativo no início da década de vinte, marcado por atitudes contrárias à República.

Nos anos entre 1919 a 1922, a classe militar emprega as sombras da impunidade em seu próprio favor. Paralelamente, as sombras da pretensão imperial de ocupar, através da "grande guerra", uma posição política central no expansionismo europeu resultam numa corrente política formada pelos sobreviventes da guerra. Estes são as bases dos partidos de extrema-direita, que tentam a todo custo derrubar a república.

Tucholsky se remete à hierarquia inquestionável do exército e critica a elite social do governo imperial. Tais regras de conduta baseiam-se na noção de gradiente de poder, são inerentes ao processo de formação de um Estado e ocorrem quando membros de classe inferior devem mostrar justamente sua condição em seu relacionamento com os de classe superior "através da obediência a um ritual formal". ${ }^{30}$ Observamos como esse fator é analisado por Tucholsky: a partir de uma determinada colocação da postura engajada assumida pelo crítico, criam-se respostas baseadas na apresentação de trechos das obras selecionadas e em um diálogo com o leitor, transferido da esfera literária para a do jornalista político. Esse diálogo corrobora a elaboração e a defesa de sua postura antimilitarista.

Os artigos de Tucholsky destacam regularmente a manipulação da realidade pelos militares e a correspondente ligação com a não-responsabilidade para assinar o Tratado de Versalhes, liame que se baseia na manutenção do status considerado intocável pelos militares. O uso do sarcasmo ou da ironia, recurso mais elementar do pathos na obra de Tucholsky e que revela o desejo ético que se esconde por trás de sua escrita, busca apontar para a verdadeira face das notícias veiculadas pelos oficiais, no sentido de mostrar a representação negativa dos discursos militares na recente estrutura política.

\subsection{A ORAÇÃO FÚNEBRE: COERÇÃO MILITAR E IMPRENSA}

Neste sentido, buscamos observar no texto intitulado $A$ oração fúnebre e veiculado em 1919 a manifestação contrária à constituição de governos com

${ }^{30}$ ELIAS, Norbert. Mudanças nos padrões europeus de comportamento no século XX. In: A literatura pró-guerra da República de Weimar (Ernst Jünger), op. cit., p. 39. 
tendências totalitárias. Neste texto, o tema central é a função da imprensa como correspondente das notícias de guerra e da sua repercussão dentro das camadas inferiores do exército. Esse texto refere-se à publicação da obra $O$ drama do Marne de 15 de julho de 1918, escrito pelo tenente Kurt Hesse e pertencente à literatura de guerra - ou, nos termos de Tucholsky, à "maré de desculpas" escritas por oficiais. ${ }^{31} \mathrm{~A}$ obra de Hesse expõe a contradição entre a realidade defendida pelo alto escalão militar e a relatada — vivida - pelo autor, ele mesmo oficial.

Como o próprio título O drama do Marne de 15 de julho de 1918 indica, a obra relata a batalha ocorrida poucos meses antes do final da guerra. $O$ período de março a agosto de 1918 registra a ofensiva do exército alemão em suas últimas forças diante da contraofensiva dos franceses e dos ingleses em 8 de agosto - "o dia negro do exército alemão"32 - e diante da posterior desagregação das tropas alemãs em duas partes. Um grupo permanece fiel aos ideais de batalha e continua persistindo em lutar apesar da visível derrota. Outro grupo não vê mais possibilidades de vitória, recusando-se a arriscar a vida em uma inevitável derrota. $\mathrm{Na}$ batalha em questão, essas divisões internas já estão constituídas e, após a guerra, os integrantes do primeiro grupo buscam fruir a condição extra-estatal da violência, persistindo à sombra do ethos militar, e os do segundo tentam reassumir a existência cotidiana.

No ensaio de Tucholsky, a censura exercida pelos militares e a alteração das notícias de guerra fazem parte de um sistema de controle militar que parece debater-se contra sua própria tentativa de ocultar a incapacidade de ocupar posições mais elevadas de poder fora de seus territórios. O desejo de conquistar os povos "bárbaros" fora da Alemanha não poderia se deparar com sua total falta de realização: para adiar a frustração das camadas do poder, apostam-se as últimas forças na continuidade do desenvolvimento militar.

Essa força mantenedora da unidade de poder militar que se reflete na imprensa, no período de 1914-1918, advém da camada dos oficiais. Tenta-se, antes de tudo, negar a realidade do próprio declínio face às mudanças adversas. Com efeito, o ano de 1918 marca a ascensão de uma classe marginal durante os anos anteriores - a classe média - e o desaparecimento do antigo establishment, defendido pelo governo imperial através das batalhas. Nova-

31 TUCHOLSKY, Kurt. Leichenreden. In: GEROLD-TUCHOLSKY, Mary; RADDATZ, Fritz J. (Org.). Gesammelte Werke, op. cit., p. 134.

32 HAFFNER, Sebastian. Von Bismarck zu Hitler: Ein Rückblick. München: Knaur, 2009, p. 147. 
mente tocamos num ponto fundamental, quando pensamos na década de 1920 alemã: a ascensão da classe média moderada diante da tentativa de manutenção dos antigos valores militares. Estes são responsáveis, segundo Tucholsky, por "omissões e mentiras sobre batalhas aéreas [Fliegerei] [...], mentiras sobre a situação de saúde e sobre a fome dos adversários." 33 Para Tucholsky, um dos problemas centrais na estrutura hierárquica de poder na Alemanha da Primeira Guerra consiste na obediência irrestrita ao representante de um status bastante elevado no império, tanto socialmente quanto em termos de poder.

A manutenção do espírito militar nos anos iniciais da República de Weimar, com suas ramificações no âmbito político, aponta para o recrudescimento do sentimento nacionalista que inflama os discursos conservadores dos partidos de direita. Em suas análises, Tucholsky ressalta, dentre outros fatores, como as ordens impostas pelas camadas superiores e incorporadas pelas camadas inferiores, além da criação de um caminho único, são euforicamente recebidas. Desta junção desdobra-se a tendência para a necessidade prosaica de um líder no seio da juventude alemã pós-guerra, a qual não se identifica com a república e busca refúgio, no que tange à literatura, na glorificação de personagens históricos.

Esse processo neorromântico marcado pelo não-estar ali corrobora a criação de "um amálgama impetuoso e venenoso para os espíritos suscetíveis"34 e desperta um sentimento que, apesar das nuances, está presente em Weimar: o caráter nacional, constituído de "elementos do código aristocrático de comportamento e sentimento [que] penetraram nos códigos das classes trabalhadoras, no decorrer de sua ascensão social." ${ }^{35} \mathrm{O}$ caráter nacional é configurado por modelos de comportamento da aristocracia militar "absorvidos por vastas seções da burguesia no período após 1871 " ou, mais precisamente, pela "tradição especificamente alemã no código de comportamento e sentimento". ${ }^{36}$ Encontramos igual leitura desta penetração de valores aristocráticos militares, compostos por membros descendentes da aristocracia alemã em nossas análises: enquanto Elias aponta também para outros setores da hierarquia social, os textos de Tucholsky indicam o processo dentro

\footnotetext{
${ }^{33}$ Cf. TUCHOLSKY, Kurt. Leichenreden, op. cit., p. 134.

${ }^{34}$ Cf. GAY, Peter. A cultura de Weimar, op. cit., p. 104.

35 ELIAS, Norbert. Duelo e filiação na classe dominante imperial. In: A literatura pró-guerra da República de Weimar (Ernst Jünger), op. cit., p. 69.

36 Ibidem.
} 
de um único espectro, o militar.

O processo descrito por Tucholsky, a partir de O drama do Marne - a necessidade de seguir uma figura de liderança - tem efeitos negativos. Nesse sentido, o oficial, "criado para líder, [...] era o amparo na batalha. As pessoas se uniam ao redor dele [e] simplesmente não sabiam onde deveriam atuar sem o líder." 37 Tucholsky denomina o oficial como a representação máxima da "ausência de espírito" (Ungeist) presente no país. O ataque ao espírito militar é um Leitmotiv em sua atuação como jornalista, expandindo sua crítica à estruturação de movimentos contrários à manutenção da república.

Tucholsky não se coloca como defensor arguto desta república em termos absolutos. Deseja, por um lado, a solidificação do novo sistema, mas condena, por outro, seu modo de sustentação do poder, no qual ramificam elementos contraditórios: o velho espírito militar e monárquico. Portanto Tucholsky é, antes, um crítico às estruturas paradoxais do novo sistema de governo, e não ao sistema republicano em si e sua concepção da realidade é contrária à guerra e à manifestação dos militares na sociedade. A postura contra os elementos dúbios na formação e sustentação da república constitui mais um fator de coerência na construção da crítica de Tucholsky nos anos posteriores do que contradições de ideias e defesa de uma visão de mundo, o que o torna um crítico do espectro do passado no presente.

\subsection{MILITARIA: UMA CRÍTICA AO “UNGEIST" MILITAR ALEMÃO}

O "Ungeist" militar alemão e sua atuação na guerra são as bases dos argumentos presentes no artigo Militaria, igualmente veiculado em 1920 no periódico Die Weltbühne. Nesse ensaio, aborda-se a pequena escrita Charleville, cujo autor, Wilhelm Appens, pertence ao esquecimento histórico.

O crítico entende a influência negativa da "ausência de espírito" a outras esferas de atuação, como a cultura, que toma o caráter de paradoxal ausência de si mesma, na "Unkultur". Numa concordância entre o ideal do crítico (político) e suas ações na construção desse discurso crítico, Tucholsky cria uma espécie de depoimento contra o ambiente de lugubridade estrutural no início dos anos vinte, marcado pelo trauma causado pelo combate.

É a partir da exposição de sua postura contrária que o crítico questiona: "o

${ }^{37}$ Cf. TUCHOLSKY, Kurt. Leichenreden, op. cit., p. 135. 
veredicto que eu frequentemente publico aqui contra os oficiais alemães é falso ou verdadeiro?"38 A interrogação aproxima ideologias diferentes e convida o leitor a discutir sobre o veredicto, construído com base na negação dos valores impostos pelos oficiais, os quais constituem o estrato nobre que vê o decréscimo gradual de poder a partir da industrialização e sente reduzir sua parcela das relações de força com a perda de sua "posição privilegiada na estrutura do Estado." 39 Vejamos como Tucholsky elabora a resposta à sua pergunta.

Todo veredicto contra uma coletividade é, em termos matemáticos, falso. O tipo que surge através de cópias sobrepostas de fotografias não existe totalmente. O que está subjacente à crítica é tipo puro [in Reinkultur] como ele é concebido por todos os componentes de determinada sociedade, é aquele tipo pelo qual todos se guiavam, é o tipo que muitos consideraram uma glória por quase terem-no alcançado por completo - é justamente "o" oficial alemão. Quem é que, hoje ainda, ousa contestar, em face de milhões de testemunhas alemãs, que oficiais alemães sumiram com os bens do exército na guerra, negaram provisões aos seus inferiores, viveram melhor do que lhes convinha e abusaram de sua posição? Quem? Os antigos chefes de propaganda política de Ludendorff. Eles sabem o porquê. E nós também. ${ }^{40}$

Do trecho derivam dois fatores. O primeiro é que a análise do crítico parte do ataque ao indivíduo para se ater à realidade dos fatos; pondera até que ponto pode-se atacar essa classe, pois existem também os militares (em sua maioria, pertencentes ao baixo escalão) contrários às medidas tomadas pelos representantes do Estado-Maior. Para que possua valor de julgamento, a crítica analisa o espectro do problema para ampliá-lo e envolver em seu novelo o ápice do problema encarnado em Ludendorff, figura símbolo de coerção externa cujos malabarismos políticos isentam-no de assumir responsabilidade pela derrota.

As discussões sobre a guerra perdida são elaboradas com base na explanação da diferença entre o ethos militar divulgado por uma casta - termos coletivos - e as consequências das ações dos militares - termos individuais. Segundo Tucholsky, um dos principais fatores responsáveis pelo "Ungeist"

38 Idem. Militaria. In: GEROLD-TUCHOLSKY, Mary; RADDATZ, Fritz J. (Org.). Gesammelte Werke, op. cit., p. 264.

39 ELIAS, Norbert. O declínio do monopólio estatal da violência na República de Weimar. In: A literatura pró-guerra da República de Weimar (Ernst Jünger), op. cit., p. 196.

${ }^{40}$ Cf. TUCHOLSKY, Kurt. Militaria, op. cit., p. 265. 
militar são os relatos fraudados sobre acontecimentos da guerra. Os resultados da derrota são o abalo da supremacia ideológica militar e a confirmação do fracasso na luta decisiva pelo controle na Europa e pela expansão territorial. Tucholsky expõe um dos principais problemas - a deturpação dos fatos pelos militares - através de questões que procuram dialogar com o leitor. Tenta mostrar, sobretudo, obras cujo conteúdo se torna fonte de possíveis análises para a compreensão de fatores culturais por meio da apresentação de fatos históricos e a partir da observação dos reflexos desses acontecimentos na sociedade.

O segundo fator é a diferença entre a posição então assumida pelos oficiais e por outras camadas da população, o que resulta no ódio e desprezo dos trabalhadores face aos militares, e vice-versa. Enquanto o proletariado organiza revoluções para reestruturar o sistema democrático, os militares desejam readquirir o velho prestígio, no ambiente da república, seja por violência estatal ou extra-estatal. Assim, se apenas os antigos chefes de propaganda de Ludendorff contestam a existência dos feitos do passado, este é um fato que confirma a crença em seus valores superiores de poder em relação a outros setores da sociedade.

Tudo o que foi roubado dos quartéis dos oficiais e dos altos funcionários é motivo de escárnio para qualquer descrição. Os guarda-roupas há muito estavam vazios. Mesas, cadeiras, camas, louças, talheres e relógios sumiram. Até mesmo instalações sanitárias foram roubadas e levadas. Mais tarde, tais saques adquiriram feições cada vez mais crassas. Obras de arte, vestidos de seda, roupas íntimas, tudo desapareceu com a saída do grande quartel-general. ${ }^{41}$

Mentiras, abuso da hierarquia para obter vantagens e uso generalizado de bebidas alcoólicas - ferramenta para se distanciar de uma realidade indesejada - são aspectos abordados também nessa passagem do artigo. A apresentação desses argumentos pelo autor de Charleville concorre para mostrar a conduta do espírito militar alemão em 1914-1918 e como as atitudes extremas marcam o desenvolvimento final da guerra dentro da corporação de oficiais alemães. Nesse momento, roubos, saques e consumo total de adegas particulares (o livro se refere aos atos oficiais praticados por um destacamento numa determinada região francesa) marcam o comportamento militar face às regiões conquistadas e, a partir de 1916, durante os momentos de der-

${ }^{41}$ Ibidem, p. 266. 
rota e posteriormente na marcha de retorno ao país. O veredicto final de Tucholsky é condenatório:

\begin{abstract}
Ausência de auto-dominação, egoísmo, submissão com os de cima e crueldade com os de baixo: eis as características do oficial alemão. Depois do "choque breve de novembro" eles revelaram novamente a ponta dos capacetes. Aqui está a questão central da educação da juventude e o ponto principal da nossa vida pública. Depende de vocês. Eliminem a militária alemã - e terão uma cultura alemã. 42
\end{abstract}

Nas críticas às obras pró-guerra e antiguerra, Tucholsky busca a apresentação dos acontecimentos abordados nas obras e a concomitante discussão cujo objetivo final é o veredicto sobre a existência dos militares, prejudiciais à sociedade e ao meio político, como se observa em todo o decorrer da República de Weimar, em escalas que se ajustam às necessidades do momento.

\title{
3. À GUISA DE CONCLUSÃO: OS APUNHALADOS
}

Finalizamos as discussões com um verdadeiro manifesto contra os militares: o texto Os apunhalados, veiculado em 1922. Pode-se dizer que sua concepção de mundo para elaborar seu veredicto busca explanar a disseminação do espírito militar em detrimento da personalidade individual, relegada a um segundo plano na constituição social. Posteriormente, busca mostrar como as mazelas oriundas dos estratos superiores alastram-se igualmente por toda a corporação de oficiais. Concomitantes a esses fatores, a análise e a crítica de Tucholsky atém-se a um importante elemento: o espírito militar é um fator histórico e, consequentemente, integrante do habitus do Estado. Esses aspectos histórico e social são analisados pelo crítico em Os apunhalados:

O espírito da corporação de oficiais alemães não paira no ar: essência e portadores são os integrantes desta casta, os quais semeiam este espírito através da educação, persuasão, paradigmas e opressão de geração a geração. A afirmação de que os oficiais alemães não valiam nada é falsa, se se observar isoladamente as pessoas simplesmente, homem a homem; é verdadeira se se observar que, acima de tudo, são oficiais. ${ }^{43}$

42 Ibidem, p. 272.

43 Idem. Die Erdolchten. In: GEROLD-TUCHOLSKY, Mary; RADDATZ, Fritz J. (Org.). Gesammelte Werke. Reinbek bei Hamburg: Rowohlt, 1993b, p. 152. 
A essência militar e a deturpação grupal oriunda da representação dessa casta passam a ser algo quase palpável, fato que se deve à existência daqueles que as defendem e as incorporam. A análise dessa casta torna-se válida na medida em que se observa, em uma perspectiva sócio-histórica, a comunhão da ideologia militar com a validação do status quo adquirido. Esse argumento é um fio condutor da produção jornalística de Tucholksy e se amplia para expor a individualidade dos crimes defendidos pelos militares contra determinadas personalidades políticas enquanto reflexos dessa violência crescente no seio da população civil. A casta militar parece não querer ver barreiras à negação de seu espírito no meio civil nem à manifestação de sua derrocada após 1918 . Tucholsky sintetiza suas reflexões críticas e amplia seus elementos constituintes no seguinte trecho:

\begin{abstract}
Não pode ser imposta, assim sem mais nem menos, somente a uma casta a responsabilidade pela brutalidade de seus integrantes. Mas no momento em que a casta, em puro silêncio ou em alarde, aprova tais crimes, ela se declara solidária aos criminosos e, a partir de então, pode ser apontada, como se ela mesmo houvesse pecado. O general que, no dia do assassinato de Erzberger, declarou ao telefone, em Berlim: "Graças a Deus aquele porco está morto! Agora vou ao porão buscar para mim uma garrafa de vinho propícia à situação!" apenas expressou o que a esmagadora maioria desses seres mercenários, que vagabundeiam pelo país e sempre planejam atos de alta traição, pensa sobre isso. Em inumeráveis artigos de jornal, em discursos e informações de uma determinada camada de oficiais, o assassinato político foi romantizado como primeiro, único recurso para o embrutecimento moral deste círculo e para sua síncope espiritual - uma prova da do embrutecimento moral destes e de sua impotência espiritual. ${ }^{44}$
\end{abstract}

A repercussão do assassinato, em agosto de 1921, de Matthias Erzberger, responsável pela assinatura do Tratado de Versalhes em 1919, é tão grande como a que se segue à morte do Ministro das Relações Exteriores Walther Rathenau, em junho de 1922, após a assinatura do Tratado de Rapallo, proposto pelos russos para firmar a paz entre os dois países. Ambos os assassinatos não constituem fatos isolados na história da república. No ano de 1919, os redatores do periódico comunista die Rote Fahne e membros da Liga Espartacus, Karl Liebknecht e Rosa Luxemburg, são torturados e mortos, assim como Kurt Eisner, um dos responsáveis pela criação da "República de Munique",

\footnotetext{
44 Ibidem, p. 153.
} 
Gustav Landauer, político socialista, e Hugo Haase, membro do Partido Socialdemocrata. Tucholsky examina e critica a responsabilidade das milícias paramilitares, cujos perpetradores são raramente vítimas de punição.

Observamos, ao cabo das reflexões propostas neste artigo, que a presença de militares e de organizações paramilitares na República de Weimar é o tema central dos textos de crítica política de Tucholsky publicados no periódico Die Weltbühne nos três anos iniciais do novo governo. Elas se solidificam e se tornam o ponto originário para ampliação de uma análise social cuja estruturação é observada em uma perspectiva também histórica, a partir da qual é expresso o processo por que passa o habitus militar no contexto de produção da obra. A consequência dessa análise é a condenação final do culto total à hierarquia que, como a própria história político-cultural da República de Weimar atesta, resulta numa forma de governo baseada em contradições que hão de se manifestar na história a partir de 1933. 